\title{
Initial development of lettuce in vermicompost at higher trichoderma doses
}

\section{Maria MS Wiethan; Gabriel S Bortolin; Renata S Pinto; Antonio Carlos F Silva}

Universidade Federal de Santa Maria (UFSM), Santa Maria-RS, Brazil; mediasaccol@gmail.com; gabrielbortolin91@gmail.com; renatasoares261@gmail.com; acfsilva2@uol.com.br

\begin{abstract}
The study aimed to evaluate the initial development, as well as, the chemical characteristics of lettuce plants grown in substrate with high concentrations of bioagent (trichoderma). A completely randomized design with four replicates was used. The treatments, applied to a substrate composed of a blend of vermicompost and commercial substrate, were established by the following doses of the commercial product ICB Nutrissolo Trichoderma: T1) 0.0; T2) 1.0; T3) 2.0; T4) 4.0; T5) 8.0 and T6) $16.0 \times 10^{11}$ conidia $\mathrm{kg}^{-1}$ of product. After inoculation, the substrate was placed in trays, where 50 lettuce seeds were sown on each replication. Plants were thinned after emergency stabilization, maintaining ten seedlings per tray. At 28 days after sowing, the characteristics percentage and emergence speed index, leaf area, fresh and dry leaf biomass, volume, length and surface area of the root were evaluated. We also determined the chemical characteristics of the leaves. The percentage of seed germination and the emergence speed index were lower at doses higher than $4.0 \times 10^{11}$ conidia $\mathrm{kg}^{-1}$ of the biological product. All the studied doses influenced negatively in shoot and root development of the plants. The percentage of nutrients in the leaves was higher in treatments with ICB.
\end{abstract}

Keywords: Lactuca sativa, Trichoderma spp., earthworm, substrate, emergence, growth.

\section{RESUMO}

Desenvolvimento inicial de alface em vermicomposto sob doses superiores de trichoderma

O trabalho teve por objetivo avaliar o desenvolvimento inicial, bem como as características químicas de plantas de alface cultivadas em substrato com elevadas concentrações do bioagente trichoderma. Foi utilizado um delineamento inteiramente casualizado, com quatro repetições. Os tratamentos aplicados em um substrato composto por uma mistura de vermicomposto e substrato comercial, foram estabelecidos pelas seguintes doses do produto comercial ICB Nutrissolo Trichoderma: T1) 0,0; T2) 1,0; T3) 2,0; T4) 4,0; T5) 8,0 e T6) $16,0 \times 10^{11}$ conídios $\mathrm{kg}^{-1}$. Após a inoculação, o substrato foi colocado em bandejas, onde foram semeadas 50 sementes de alface $\mathrm{cv}$. Regina por repetição. Fez-se um desbaste após a estabilização da emergência, havendo a manutenção de dez plântulas por bandeja. Aos 28 dias após a semeadura, foram avaliadas as características porcentagem e velocidade de emergência, área foliar, fitomassa fresca e seca das folhas, assim como o volume, comprimento e área superficial de raiz. Fez-se também a determinação das características químicas das folhas. A porcentagem e o índice de velocidade de emergência de plântulas foram menores em doses acima de $4,0 \times 10^{11}$ conídios $\mathrm{kg}^{-1}$ do produto biológico. Todas as doses estudadas influenciaram negativamente $\mathrm{o}$ desenvolvimento aéreo e radicular das plantas. A porcentagem de nutrientes nas folhas foi superior na presença de trichoderma.

Palavras-chave: Lactuca sativa, Trichoderma spp., minhoca, substrato, emergência, crescimento.

\section{Received on November 16, 2016; accepted on August 3, 2017}

$\mathrm{O}$ rganic agriculture has been widely diffused in Brazil in the last years, since it represents options for healthier diet, and a growing concern with environmental preservation, community development and incentive to family farming. The use of organic farming offers alternatives for reduction of pesticide use, substituting this product for less aggressive agents to the environment. In Brazil, vegetables are grown organically mainly in the South, Southeast and Central-West regions, being lettuce (Lactuca sativa) one of the main leafy vegetables cultivated in the Country. Since this vegetable is consumed in natura worldwide, it shows high risks of contamination by agricultural pesticides used for chemical control of phytopathogens (Paulitz $\&$ Bèlanger, 2001). Thus, the use of biological control agents becomes an indispensable tool.

The limited use of trichoderma (Trichoderma spp.) as a biocontrol agent justifies its lower applicability to the biocontrol of diseases and promotion of plant growth in agriculture, being restricted to the availability of legally registered commercial products
(Machado et al., 2012). Several studies which characterize the biological aspects of this bioagent, especially those involving the process of inhibiting phytopathogen development, can be found in literature (Verma et al., 2007). However, promotion of plant growth by applying some trichoderma isolates, initially justified for controlling harmful microorganisms present in soil, has been also related to hormone production and to an increase of some nutrients absorption by the plant in the presence of this bioagent, and even in the absence of phytopathogens (Machado et al., 
2012).

The correct dose application of the biological product must be considered. Some studies have been showing the beneficial effect of the trichoderma isolates for promoting plant development and controlling diseases affecting crops of cotton (Shanmugaiah et al., 2009), beans (Hoyos-Carvajal et al., 2009) and vegetables (Celar \& Valic, 2005) using recommended doses. Few studies on the use of doses higher than the recommended which may cause any negative effects of the vermicompost on plant growth can be found, though.

Several abiotic and biotic factors can influence the action of trichoderma, such as the substrate, the type of crop, rhizospheric microorganisms, as well as the isolates, forms of inoculum and high concentrations of the antagonist (Hajieghrari, 2010). The concentrations of the antagonist, which still need more studies, were used in the study of Hassan et al. (2013) by using large amount of Trichoderma viride inoculum in the treatment of Striga hermonthica seeds and generated negative effects on the germination process.

Trichoderma, when applied at high doses on the roots, caused toxicity associated with inhibition of plant growth due to an increase in concentration of ammonium ions (Neumann \& Laing, 2007). Experiments confirm that the nitrogen in the form of ammonium is more inhibitory than in the form of nitrate but, it is known that ammonium causes significant losses in root elongation and seed germination (Celar \& Valic, 2005). Studies also report that trichoderma isolates can produce auxin-inducing or similar substances which, in higher concentrations than the optimal one, show an inhibitory effect on seed germination and on seedling development (Vinale et al., 2008a,b).

Evaluating the inoculation of large amounts of trichoderma, Kohl \& Schlösser (1989) concluded that this bioagent reduced partially germination of sugar beet seeds and inhibited root growth; this fact is related to the formation of alkyl-pyrone, capable of inhibiting the development of some plant species. Similarly, Cutler et al. (1989) verified that Koninginin-A metabolite produced by Trichoderma koningii inhibited the growth of wheat coleoptiles.

Given the above, this study aimed to evaluate the possible negative effect of higher doses than the recommended of ICB Nutrisolo Trichoderma on germination, initial development and chemical composition of lettuce aerial part.

\section{MATERIAL AND METHODS}

The experiment was done during the first semester of 2015, in the Laboratories of Soil Biology, Tissue Analysis and at the greenhouse of Department of Soil and Plant-Microorganism Interaction Laboratories and Plant Physiology and the Biology Department at Universidade Federal de Santa Maria (UFSM), Santa Maria, Rio Grande do Sul, Brazil. The adult and clitellate earthworms Eisenia andrei were provided by the worm farm of the Department of Soil, UFSM. As a source of biological agent (trichoderma), the authors used the commercial product ICB Nutrisolo Trichoderma in the form of fluid, composed of eight strains of Trichoderma koningiopsis, Thrichoderma asperellum and Trichoderma harzianum, at the concentration of $10^{11}$ conidia $\mathrm{mL}^{-1}$, with registration in MAPA (Ministry of Agriculture, Livestock and Food Supply): RS12734/10000-4 (Art. 15 annex to Decree 4954/2004), provided by ICB BIOAGRITEC LTDA.

Production of vermicomposted substrate at high doses of trichoderma - In order to test doses higher than the recommended of the commercial product ICB Nutrisolo Trichoderma (ICB) for emergence and initial development of lettuce plants, cv Regina, the authors used doses, increasing and superior to $10^{6}$ conidia $\mathrm{kg}^{-1}$, described recently for T. asperullum by Sadykova \& Kurakov (2013) for vermicompost. The cattle manure in natura used for producing the vermicompost was from milk cattle and it was obtained at a rural property in the municipality of Santa Maria-RS.

Treatments were arranged in a completely randomized design, with four replicates, after homogenization and autoclaving of the manure at $121^{\circ} \mathrm{C}$ twice, at a 24-hour interval. Each experimental unit was represented by a polypropylene multipurpose box, with dimensions of $20 \times 40 \times 50 \mathrm{~cm}$ and $10-\mathrm{L}$ capacity, into which the authors added $6 \mathrm{~kg}$ of manure with the following chemical analysis: water $\mathrm{pH}=7.8 ; \mathrm{C}$ $(\%)=23.2 ; \mathrm{N}(\%)=1.78 ; \mathrm{C} / \mathrm{N}=13.1$; $\mathrm{P}(\%)=2.23 ; \mathrm{K}(\%)=0.05 ; \mathrm{Ca}(\%)=$ $1.71, \mathrm{Mg}(\%)=0.41$, according to the methodology proposed by Tedesco et al. (1995). The evaluated treatments (T) were represented by the following doses, $10^{11}$ conidia kg ${ }^{-1}$ of the product ICB: T1) 0.0; T2) 1.0; T3) 2.0; T4) 4.0; T5) 8.0 and T6) 16.0.

After the application of doses, 48 adult earthworms $E$. andrei were inoculated and clitellated in each experimental unit. For the vermicomposting process, the boxes containing cattle manure, earthworms and trichoderma were covered using brown paper. The temperature was kept at $28^{\circ} \mathrm{C}$, humidity from 60 to $70 \%$ and absence of light during the entire process. The authors carried out uniform tillage practices every seven days for aeration and humidity control. For lettuce establishment, the used substrate was composed of a blend of $50 \%$ vermicompost of each treatment and $50 \%$ commercial substrate Plantmax.

Percentage and emergence speed index - In order to evaluate the percentage and emergence speed index (ESI), the authors used completely randomized design, with four replicates. The experimental units were represented by germination trays, each one composed of ten cells. After allocating the substrates in trays, the authors seeded five lettuce seeds, cultivar Regina, per cell, at a depth of $0.5 \mathrm{~cm}$, totalizing 200 seeds per treatment.

The experimental units (trays) were kept in the greenhouse, under controlled conditions of temperature $\left(25^{\circ} \mathrm{C}\right)$ and humidity (substrate and environment). In order to determine the percentage and emergence speed index, the number of emerged seedlings was recorded until the emergency stabilization, and the ESI was calculated using the formula proposed by Maguire (1962):

$\mathrm{ESI}=\mathrm{E} 1 / \mathrm{N} 1+\mathrm{E} 2 / \mathrm{N} 2+\ldots \mathrm{Em}+\mathrm{Nn}$ 
Where: ESI $=$ emergence speed index. E1, E2, ... En = Number of normal seedlings counted in the first calculation, in the second calculation and in the last calculation. $\mathrm{N} 1, \mathrm{~N} 2, \ldots \mathrm{Nn}=$ Calculation of the number of days from the first to the last sowing. After this emergence process evaluation, plantlets were thinned, keeping one seedling per cell, totalizing ten seedlings per experimental unit.

Initial development of lettuce plants - In order to compare and differentiate the development, ten plants of each sample unit were cut at the base at 28 days after sowing and weighed for determining fresh biomass. Afterwards, all the plants were analyzed with the aid of a professional scanner (Epson XL 10000), equipped with additional light unit (TPU), high resolution of $600 \mathrm{dpi}$. The three-dimensional images were analyzed using the software WinRHIZO Pro 2013; the authors quantified the leaf surface area of leaves and roots $\left(\mathrm{cm}^{2}\right)$ and also root characteristics such as total length $(\mathrm{cm})$, volume $\left(\mathrm{cm}^{3}\right)$ and average diameter $(\mathrm{mm})$.

Then, shoots were kept in paper envelopes, properly identified and taken for drying under forced ventilation system, at a temperature of $65^{\circ} \mathrm{C}$. After reaching constant weight, the authors weighed the material again in order to determine dry biomass.

Chemical analysis of the above ground part - In order to determine $\mathrm{Ca}, \mathrm{Mg}, \mathrm{P}$ and $\mathrm{K}$ of the above ground part, the dried material was ground and submitted to a tissue analysis, according to the methodology proposed by Tedesco et al. (1995).

Statistical analysis - The authors used analysis of variance (ANOVA) and the averages were compared using Scott Knott test $(p \leq 0.05)$. All the evaluated parameters were submitted to the regression analysis. The statistical analyses were done using software BioEstat 5.0 (Ayres et al., 2007).

\section{RESULTS AND DISCUSSION}

The results for emergence percentage and emergence speed index (ESI) of lettuce plants in substrate inoculated with higher and increasing doses of ICB Nutrisolo Trichoderma (Figure 1) showed reduction tendency in these parameters in relation to the control. Using the regression analysis, the authors noticed a quadratic adjustment for the two evaluated variables. For percentage (Figure 1A) and speed index (Figure 1B) of emergence in initial doses 1,2 and $4\left(10^{11}\right.$ conidia $\left.\mathrm{kg}^{-1}\right)$, no significant reduction in the results in comparison to the control treatment was verified.

Effect of trichoderma on the emergence percentage and ESI seems to be dependent on the isolate. Ozbay \& Newman (2004) verified, through inoculation into substrate of two isolates of T. harzianum (T-22 and T-95) at the concentration $10^{7}$ conidia $\mathrm{mL}^{-1}$, no effect on the emergence in tomato when compared to the control. The use of culture filtrates of Trichoderma longibrachiatum and $T$. viride by Celar \& Valic (2005) provided a significant reduction of the first and last calculation of onion seed germination.

The reduction of seed germination percentage and initial development of plants by trichoderma may be related with a variety of secondary metabolites generated by their isolates. As an example, viridiol is a phytotoxin produced by some species

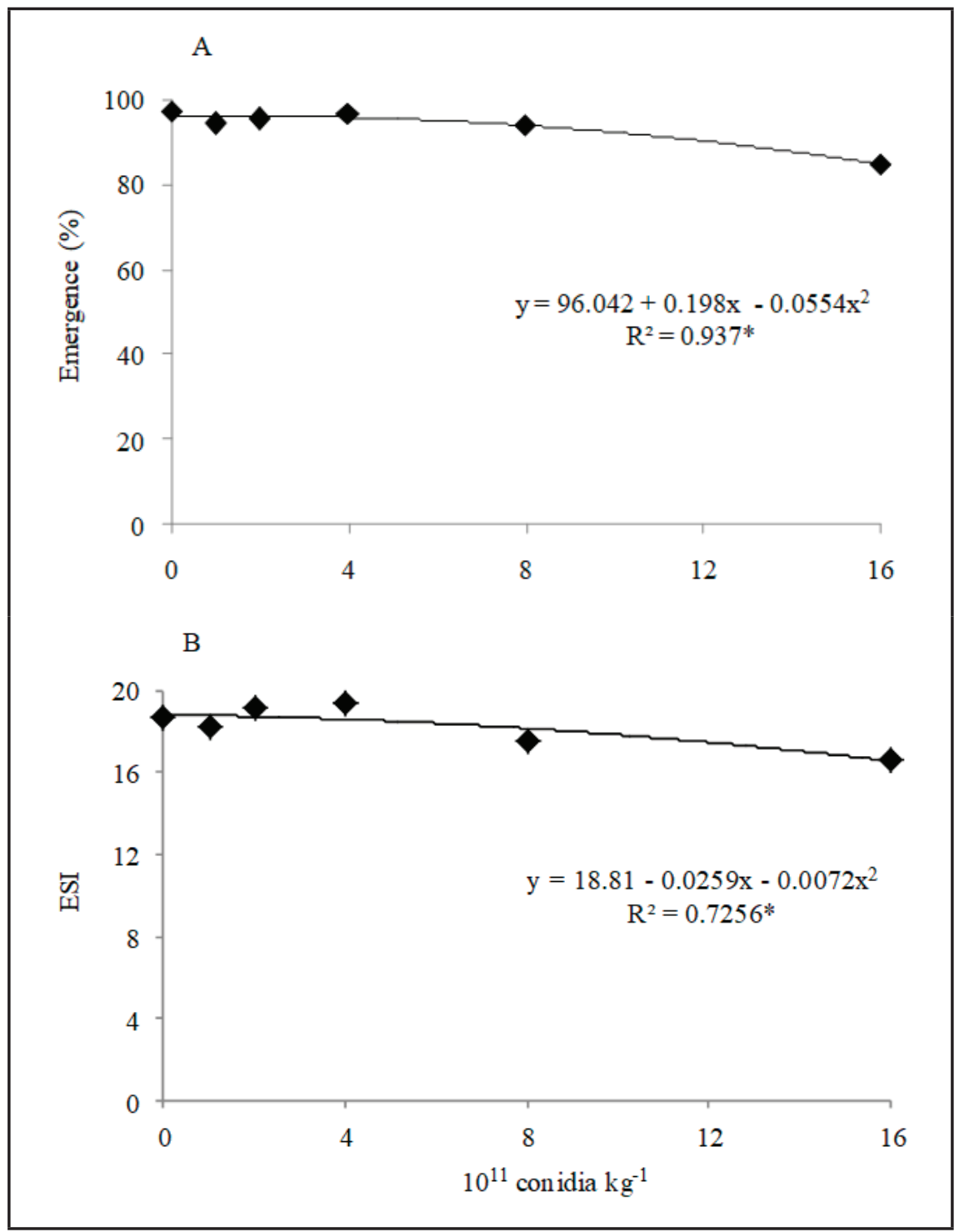

Figure 1. Emergence percentage (A) and emergence speed index values (B) of lettuce seedlings in substrate treated with higher doses of the commercial product ICB Nutrisolo Trichoderma; *significant at 1\%. Santa Maria, UFSM, 2015. 
of trichoderma (Moffatt et al., 1969) which has retarding effect on lettuce seed germination (Jones et al., 1988). Results which show that the increase in the concentration of trichoderma

affected germination process were verified by Hassan et al. (2013), when using concentration of $6 \times 10^{1}$ conidia $\mathrm{mL}^{-1}$ of $T$. viride in the presence of the biostimulant GR24 observed a

Table 1. Biomass values of fresh and dry leaves (FF; FS) and fresh roots (FR), surface area of leaf and root (AF; AR), as well as the volume, length and average diameter of lettuce plant roots at 28 days after sowing in the substrate treated with higher doses of the commercial product ICB Nutrisolo Trichoderma. Santa Maria, UFSM, 2015.

\begin{tabular}{|c|c|c|c|c|c|c|c|c|}
\hline \multirow{2}{*}{$10^{11}$ conidia $\mathrm{kg}^{-1}$} & \multicolumn{6}{|c|}{ Phytomass (g) } & \multirow{2}{*}{\multicolumn{2}{|c|}{$\begin{array}{c}\text { Leaf area } \\
\left(\mathrm{cm}^{2}\right)\end{array}$}} \\
\hline & \multicolumn{2}{|c|}{ Fresh leaf } & \multicolumn{2}{|c|}{ Dry leaf } & \multicolumn{2}{|c|}{ Fresh root } & & \\
\hline 0.0 & \multicolumn{2}{|c|}{$7.09 \pm 3.27 \mathrm{a}$} & \multicolumn{2}{|c|}{$0.74 \pm 0.34 \mathrm{a}$} & \multicolumn{2}{|c|}{$5.4 \pm 1.73 \mathrm{a}$} & \multicolumn{2}{|c|}{$242.31 \pm 98.94 \mathrm{a}$} \\
\hline 1.0 & \multicolumn{2}{|c|}{$1.67 \pm 0.51 \mathrm{~b}$} & \multicolumn{2}{|c|}{$0.13 \pm 0.01 \mathrm{~b}$} & \multicolumn{2}{|c|}{$1.87 \pm 0.63 \mathrm{c}$} & \multicolumn{2}{|c|}{$61.75 \pm 18.52 b$} \\
\hline 2.0 & \multicolumn{2}{|c|}{$2.28 \pm 0.93 \mathrm{~b}$} & \multicolumn{2}{|c|}{$0.17 \pm 0.05 \mathrm{~b}$} & \multicolumn{2}{|c|}{$3.45 \pm 1.15 \mathrm{~b}$} & \multicolumn{2}{|c|}{$79.76 \pm 30.05 \mathrm{~b}$} \\
\hline 4.0 & \multicolumn{2}{|c|}{$1.60 \pm 0.56 \mathrm{~b}$} & \multicolumn{2}{|c|}{$0.12 \pm 0.04 \mathrm{~b}$} & \multicolumn{2}{|c|}{$2.44 \pm 0.53 \mathrm{c}$} & \multicolumn{2}{|c|}{$60.71 \pm 18.82 \mathrm{~b}$} \\
\hline 8.0 & \multicolumn{2}{|c|}{$2.58 \pm 0.42 \mathrm{~b}$} & \multicolumn{2}{|c|}{$0.19 \pm 0.05 \mathrm{~b}$} & \multicolumn{2}{|c|}{$3.80 \pm 0.68 \mathrm{~b}$} & \multicolumn{2}{|c|}{$28.63 \pm 2.81 \mathrm{c}$} \\
\hline 16.0 & \multicolumn{2}{|c|}{$1.99 \pm 0.29 \mathrm{~b}$} & \multicolumn{2}{|c|}{$0.17 \pm 0.04 \mathrm{~b}$} & \multicolumn{2}{|c|}{$2.32 \pm 0.30 \mathrm{c}$} & \multicolumn{2}{|c|}{$20.06 \pm 2.28 \mathrm{c}$} \\
\hline \multirow[t]{3}{*}{$\mathrm{CV}(\%)$} & \multicolumn{2}{|c|}{17.02} & \multicolumn{2}{|c|}{8.07} & \multicolumn{2}{|c|}{12.34} & 7.9 & \\
\hline & & & & Root & system & & & \\
\hline & Area & $\left.\mathbf{m}^{2}\right)$ & Volur & e $\left(\mathrm{cm}^{3}\right)$ & Leng & $\mathbf{l}(\mathrm{cm})$ & Diamete & $r(\mathrm{~mm})$ \\
\hline 0.0 & $516.1=$ & $15.2 \mathrm{a}$ & 5.01 & $1.38 \mathrm{a}$ & 4246.9 & $768.6 \mathrm{a}$ & $0.385 \pm$ & $0.03 \mathrm{a}$ \\
\hline 1.0 & 148.4 & $6.2 \mathrm{~d}$ & 1.17 & $0.21 \mathrm{c}$ & 1494.5 & $259.9 \mathrm{c}$ & $0.316 \pm$ & $0.01 \mathrm{c}$ \\
\hline 2.0 & 282.8 & $4.7 \mathrm{c}$ & 2.40 & $0.69 \mathrm{~b}$ & 2657.4 & $637.9 \mathrm{~b}$ & $0.337 \pm$ & $0.01 \mathrm{c}$ \\
\hline 4.0 & 250.7 & $3.6 \mathrm{c}$ & 2.04 & $0.49 \mathrm{~b}$ & 2455.4 & $459.3 \mathrm{~b}$ & $0.324 \pm$ & $0.01 \mathrm{c}$ \\
\hline 8.0 & 321.1 & $9.0 \mathrm{~b}$ & 2.78 & $0.36 \mathrm{~b}$ & 2945.1 & $514.3 \mathrm{~b}$ & $0.347 \pm$ & $0.01 \mathrm{~b}$ \\
\hline 16.0 & 232.9 & $0.7 \mathrm{c}$ & 2.09 & $0.24 \mathrm{~b}$ & 2067.1 & $130.1 \mathrm{~b}$ & $0.385 \pm$ & $.03 \mathrm{~b}$ \\
\hline $\mathrm{CV}(\%)$ & & & & 07 & & & 7.9 & \\
\hline Regression & FF & FS & RF & $\mathbf{A F}$ & AR & Vol & Length & Diam \\
\hline Linear & $*$ & $*$ & $* *$ & $*$ & $*$ & $*$ & $*$ & $*$ \\
\hline Quadratic & $*$ & $*$ & $* *$ & $*$ & $*$ & $*$ & $*$ & $*$ \\
\hline Cubic & $*$ & $*$ & $*$ & $* *$ & $*$ & $*$ & $*$ & $*$ \\
\hline
\end{tabular}

Averages followed by the same letter, in column, do not differ by Scott Knott test at 5\% probability. ${ }^{\mathrm{ns}, * * * *}$ not significant, significant at 5 and $1 \%$ probability respectively.

Table 2. Chemical characteristics of lettuce plant leaves at 28 days after sowing in the substrate treated with higher doses of the commercial product ICB Nutrisolo Trichoderma. Santa Maria, UFSM, 2015.

\begin{tabular}{lcccc}
\hline $\mathbf{1 0}^{11}$ conidia $\mathbf{~ k g}^{-1}$ & $\mathbf{P}(\%)$ & $\mathbf{K}(\%)$ & $\mathbf{C a}(\%)$ & $\mathbf{M g}(\%)$ \\
\hline 0.0 & $1.21 \pm 0.31 \mathrm{~b}$ & $0.40 \pm 0.03 \mathrm{~d}$ & $0.73 \pm 0.09 \mathrm{c}$ & $0.60 \pm 0.08 \mathrm{c}$ \\
1.0 & $1.93 \pm 0.41 \mathrm{a}$ & $0.89 \pm 0.11 \mathrm{a}$ & $1.56 \pm 0.10 \mathrm{a}$ & $1.28 \pm 0.15 \mathrm{a}$ \\
2.0 & $1.98 \pm 0.25 \mathrm{a}$ & $0.65 \pm 0.11 \mathrm{c}$ & $1.34 \pm 0.21 \mathrm{a}$ & $0.99 \pm 0.13 \mathrm{~b}$ \\
4.0 & $1.96 \pm 0.30 \mathrm{a}$ & $0.73 \pm 0.04 \mathrm{~b}$ & $1.44 \pm 0.07 \mathrm{a}$ & $1.09 \pm 0.06 \mathrm{~b}$ \\
8.0 & $1.83 \pm 0.04 \mathrm{a}$ & $0.57 \pm 0.05 \mathrm{c}$ & $1.12 \pm 0.10 \mathrm{~b}$ & $0.75 \pm 0.03 \mathrm{c}$ \\
16.0 & $2.27 \pm 0.30 \mathrm{a}$ & $0.55 \pm 0.08 \mathrm{c}$ & $1.07 \pm 0.13 \mathrm{~b}$ & $0.65 \pm 0.08 \mathrm{c}$ \\
\hline CV $(\%)$ & 6.28 & 3.55 & 3.87 & 3.62 \\
Linear regression & $\mathrm{ns}$ & $\mathrm{ns}$ & $\mathrm{ns}$ & $*$ \\
Quadratic regression & $*$ & $*$ & $*$ & $*$ \\
Cubic regression & $* *$ & $*$ & $*$ & $*$ \\
\hline Averages & & & & $*$
\end{tabular}

Averages followed by the same letter, in column, do not differ by Scott Knott test at 5\% probability. ${ }^{\mathrm{ns}, * * * *}$ not significant, significant at 5 and $1 \%$ probability respectively. significant increase in seed germination of Striga hermonthica $(90 \%)$ in relation to the control $(85 \%)$. However, at a high dose of $2.5 \times 10^{6}$ conidia $\mathrm{mL}^{-1}$, in the presence of GR24, total inhibition of germination was noticed. The same isolate, when used at concentrations of $2.5 \times 10^{6}$ conidia $\mathrm{mL}^{-1}$, for Mallit and ElFasher (millet varieties), respectively, provided $100 \%$ of seed germination, and at high concentration of $2.5 \times 10^{6}$ conidia $\mathrm{mL}^{-1}$, a decrease in germination percentage (78 and 92\%, respectively), as well as in vigor indexes.

The results observed for biomass of fresh and dry mass of leaves, fresh mass of roots, surface area of leaves and roots, as well as the volume, total length and average diameter of lettuce plant roots grown in the substrate with ICB Nutrisolo Trichoderma, at doses 1, 2, 4, 8 , and 16 ( $10^{11}$ conidia $\left.\mathrm{kg}^{-1}\right)$ at 28 days after sowing were lower in relation to the control (Table1). As it was observed for seedling emergence (Figure 1A and B), higher doses of $4.0 \times 10^{11}$ conidia $\mathrm{kg}^{-1}$ provided reduction in lettuce plant development. The authors could conclude using the regression analysis that most of the parameters presented a significant adjustment to the evaluated models (Table 1).

Evaluating isolates of trichoderma on corn seed germination and seedling vigor, Hajieghrari (2010) observed that the used isolates reduced seed germination percentage and decreased significantly the root length in relation to the non-inoculated seeds (control), in accordance with the results obtained in this study for emergence and root morphology (Figure 1, Table 1). In this same study, when corn seeds were exposed to spore suspension of Trichoderma $\left(10^{6}\right.$ to $10^{7}$ conidia $\left.\mathrm{mL}^{-1}\right)$, the authors observed inhibition of seed germination, as well as a decrease in root development, above ground part, leaf area, fresh root weight, fresh biomass weight when compared with the control.

Although the mechanisms by which trichoderma isolates can act as promoters of plant development are not fully elucidated, there are evidences of the production of indol acetic acid (IAA), which main functions in the superior plants consist in the regulation 
of the growth by young stem elongation (Gravel et al., 2007). Some species of trichoderma can produce auxininducing compounds, however, the high production of this phytohormone in the rhizosphere may reduce the development of the root system (Vinale et al., 2008a,b). According to Bjorkman (2004), growth rates of corn roots with high sensitivity to IAA can be reduced with addition of these phytohormones, whereas the addition of exogenous IAA in corn roots with low sensitivity to this phytohormone may result in higher growth rate.

The results found in this study (Table 1) reinforce the data obtained by Resende et al. (2004), who working with corn seeds inoculated with $T$. harzianum, did not obtain significant results for plant height and increase in shoot fresh mass. Sadykova \& Kurakov (2013) used quite lower dose of trichoderma $\left(10^{6}\right.$ conidia $\left.\mathrm{kg}^{-1}\right)$ compared to the ones used in this study in vermicompost, in cucumber crop, and obtained an increase in biomass and root system, which justifies the effectiveness of using lower doses of the mentioned growth-promoting agent not observed in the results obtained for all higher doses for shoot and root (Table 1).

Chemical analysis of the shoots of lettuce seedlings showed higher percentage of $\mathrm{P}, \mathrm{K}, \mathrm{Ca}$ and $\mathrm{Mg}$ in all studied doses of trichoderma when compared with the control, however, the authors observed some decrease in percentage of these nutrients when using doses from $8.0 \times 10^{11}$ conidia $\mathrm{kg}^{-1}$ of ICB Nutrisolo Trichoderma (Table 2). Corroborating the analysis of average test, through regression analysis, the authors could observe that all the evaluated elements showed a significant adjustment to the quadratic model.

The greater accumulation of nutrients verified in lettuce plants grown in substrate with trichoderma can be associated with a statement by Altomare et al. (1999), who attributed the greater accumulation of nutrients and the consequent promotion of plant growth to the ability of $T$. harzianum isolated T-22 to solubilize important nutrients.

Values obtained in this study are in accordance with the ones found by Beninni et al. (2005) in their study in the absence of trichoderma, which verified $\mathrm{P}, \mathrm{K}, \mathrm{Ca}$ and $\mathrm{Mg}$ values of 0.87 ; 0.23; 1.26 and $2.02 \%$, respectively; values of $\mathrm{P}$ and $\mathrm{K}$ are lower (1.21\% and $0.40 \%$, respectively) and value of $\mathrm{Mg}$ higher than the ones found in this study for all evaluated doses (Table 2). However, for $\mathrm{Ca}$, the percentage was higher up to the dose of $4.0 \times 10^{11}$ conidia $\mathrm{kg}^{-1}$ of ICB Nutrisolo Trichoderma in this study.

The increase in percentage of phosphorus observed in the presence of trichoderma is in agreement with the studies of Gravel et al. (2007), which associate greater accumulation of $\mathrm{P}$ by the plant with the ability of this bioagent to solubilize phosphate, increasing, consequently, the availability of this element. Evaluating the effect of trichoderma on chemical characteristics of beans, Rodrigues (2010) verified that the application of this biological agent into the substrate promoted $\mathrm{P}$ availability for the plant.

The use of higher doses of ICB Nutrisolo Trichoderma than the recommended, used in this study, influences negatively the initial development of shoots and roots of lettuce plant cv. Regina. However, for the parameters which are related to seed germination, the negative influence can be observed consistently when using doses higher than $4.0 \times 10^{11}$ conidia $\mathrm{kg}^{-1}$ of the biological product. The chemical analysis of the leaves shows that higher doses increase the percentage of all the evaluated nutrients.

\section{ACKNOWLEDGEMENTS}

The authors thank to ICB Bioagritec Ltda for supplying and for the availability of information on the biological product.

\section{REFERENCES}

ALTOMARE, C; NORVELL, WA; BJÖRKMAN, T; HARMAN, GE. 1999. Solubilization of phosphates and micronutrients by the plantgrowth-promoting and biocontrol fungus Trichoderma harzianum Rifai 1295-22. Applied and Environmental Microbiology 65: 2926-2933.
AYRES, M; AYRES, MJR; AYRES, DL; SANTOS, SA. 2007. BioEstat 5.0: Aplicações estatísticas nas áreas das ciências biológicas e médicas. 5. ed. Belém: Sociedade Civil Mamirauá. 364p.

BENINNI, ERY; TAKAHASHI, HW; NEVES, CSVJ. 2005. Concentração e acúmulo de macronutrientes em alface cultivada em sistemas hidropônico e convencional. Semina: Ciências Agrárias 26: 273-282.

BJORKMAN, T. 2004. Effect of Trichoderma colonization on auxin-mediated regulation of root elongation. Plant Growth Regulation 43: 89-92.

CELAR, F; VALIC, N. 2005. Effects of Trichoderma spp and Glicladium roseum culture filtrates on seed germination of vegetables and maize. Journal of Plant Diseases and Protection 112: 343-350.

CUTLER, HG; HIMMELLSBACH, DS; ARRENDALE, RF; COLE, PD; COX, RH. 1989. Koninginin A: A novel plant growth regulator from Trichoderma koningii. Agricultural and Biological Chemistry 53: 2605-2611.

GRAVEL, V; ANTOUN, H; TWEDDELL, RJ. 2007. Growth stimulation and fruit yield improvement of greenhouse tomato plants by inoculation with Pseudomonas putida or Trichoderma atroviride: possible role of indole acetic acid (IAA). Soil Biology and Biochemistry 39: 1968-1977.

HAJIEGHRARI, B. 2010. Effects of some Iranian Trichoderma isolates on maize seed germination and seedling vigor. African Journal of Biotechnology 9: 4342-4347.

HASSAN, MM; DAFFALLA, HM; MODWI, HI; OSMAN, MG; AHMED, II; GANI, MEA; BABIKER, AGE. 2013. Effects of fungal strains on seeds germination of millet and Striga hermonthica. Universal Journal of Agricultural Research 2: 83-88.

HOYOS-CARVAJAL, L; ORDUZ, S; BISSETT, J. 2009. Growth stimulation in bean (Phaseolus vulgaris L.) by Trichoderma. Biological Control 51: 409-416.

JONES, RW; LANINI, WT; HANCOCK, JG. 1988. Plant growth response to the phytotoxin viridiol produced by the fungus Gliocladium virens. Weed Science 36: 683-687.

KOHL, J; SCHLÖSSER, E. 1989. Effect of Trichoderma spp. on seedlings of sugar beet during the biological control of pathogens. Medicine Faculty Landbouw Rijksuniv 54: 707-714.

MACHADO, DFM; PARZIANELLO, FR; SILVA, ACF, ANTONIOLLI, ZI. 2012. Trichoderma no Brasil: $\mathrm{O}$ fungo e o bioagente. Revista de Ciências Agrárias (Lisboa) 35: 274-288.

MAGUIRE, JD. 1962. Speed of germination aid in selection and evaluation for seedlings emergence and vigor. Crop Sciences 2: 176177.

MOFFATT, JS; BULOCK, JD; YUEN, TH. 1969. Viridiol, a steroid-like product from Trichoderma viride. Journal of the Chemical Society D: Chemical Communications. 14: 839.

NEUMANN, B, LAING, M. 2007. A mechanism 
for growth inhibition in plants, associated with Trichoderma application. In PROCEEDINGS OF THE MEETING FUNDAMENTAL AND PRACTICAL APPROACHES TO INCREASE BIOCONTROL EFFICACY, 30. Proceedings... Spa: IOBC: p. 265.

OZBAY, N; NEWMAN, SE. 2004. Effect of Trichoderma harzianum strains to colonize tomato roots and improve transplant growth. Pakistan Journal of Biological Sciences 7: 253-257.

PAULITZ, TC; BÉLANGER, RR. 2001. Biological control in greenhouse systems. Annual Review of Phytopathology 39: 103133.

RESENDE, ML; OLIVEIRA, JA; GUIMARÃES, RM; PINHO, RGV; VIEIRA, AR. 2004. Inoculação de sementes de milho utilizando o Trichoderma harzianum como promotor de crescimento. Ciência e Agrotecnologia

$$
\text { 28: 793-798. }
$$

RODRIGUES, J. 2010. Trichoderma spp. associado a níveis de adubação NPK no patossistema Sclerotinia sclerotiorum - Feijoeiro. Santa Maria: UFSM. 85p. (Dissertação mestrado).

SADYKOVA, S; KURAKOV, AV. 2013. Prospects for the use of strains of the genus Trichoderma to obtain vermicomposts with fungicides and growth stimulating properties. Russian Agricultural Sciences 39: 257-260.

SHANMUGAIAH, V; BALASUBRAMANIAN, $\mathrm{N}$; G O M A T H I N A YA G A M, S ; MONOHARAN, PT; RAJENDRAN, A. 2009. Effect of single application of Trichoderma viride and Pseudomonas fluorences on growth promotion in cotton plants. African Journal of Agricultural Research 4: 1220-1225.

TEDESCO, MJ; GIANELLO, C; BISSANI, CA; BOHNEN, H; VOLKWEISS, SJ. 1995.
Análise de solo, plantas e outros materiais. $2^{\mathrm{a}}$ ed. Porto Alegre: Departamento de solos, UFRGS, 174p.

VERMA, M; BRAR, SK; TYAGI, RD; SURAMPALLI, RY; VALERO, JR. 2007. Antagonistic fungi Trichoderma spp: Panoply of biological control. Biochemical Engineering Journal 37: 1-20.

VINALE, F; SIVASITHAMPARAM, K; GHISALBERTI, EL; MARRA, R; BARBETTI, MJ; LI, H; WOO, SL; LORITO, M. 2008a. A noel role for Trichoderma secondary metabolites in the interactions with plants. Physiological and Molecular Plant Pathology 72: 80-86.

VINALE, F; SIVASITHAMPARAM, K; GHISALBERTI, EL; MARRA, R; BARBETTI, MJ; LI, H; WOO, SL; LORITO, M. 2008b. Trichoderma - plant - pathogen interactions. Soil Biology and Biochemistry 40: $1-10$. 